Ilmu Pertanian (Agricultural Science)

Vol. 2 No. 2 August, 2017 : 064-069

Available online at http://journal.ugm.ac.id/jip

DOI: doi.org/10.22146/ipas.18333

\title{
Shallot Growth and Yields Based on Ammonium:Nitrate Ratio on Coastal Sandy Soil
}

\author{
Wiji Safitri $^{1 *}$, Endang Sulistyaningsih ${ }^{1}$, Benito Heru Purwanto ${ }^{2}$, Stephen Harper ${ }^{3}$ \\ ${ }^{1}$ Department of Agronomy, Faculty of Agriculture, Universitas Gadjah Mada \\ Jln. Flora no. 1, Bulaksumur, Sleman, Yogyakarta 5528, Indonesia \\ ${ }^{2}$ Department of Soil Science Faculty of Agriculture, Universitas Gadjah Mada \\ Jln. Flora no. 1, Bulaksumur, Sleman, Yogyakarta 5528, Indonesia \\ ${ }^{3}$ Australian Centre for International Agricultural Research \\ 38 Thynne Street, Fern Hill Park BRUCE ACT, Australia \\ *Corresponding email: wijisafitri5@mail.ugm.ac.id
}

Received: $25^{\text {th }}$ January 2017 ; Revised: $5^{\text {th }}$ May 2017 ; Accepted: $28^{\text {th }}$ August 2017

\begin{abstract}
Nitrogen was a key component for increasing yield and quality of vegetables like shallots. The growth and development of plants were influenced by nitrogen form. Common plants preferred nitrate for growth, but the enormity preference varies within plant species and other environmental factors. The purpose of this experiment was to study the effect of ammonium:nitrate ratio in sandy soil to growth and yield of shallot (Allium cepa L. Aggregatum group). The experiment had been conducted in August-October 2015 in the sandy land on Samas Beach, Bantul, Yogyakarta, Indonesia. The research was arranged in a Split-Plot design. The main plot was the source of nitrogen $\left(\mathrm{NH}_{4}{ }^{+} ; \mathrm{NO}_{3}{ }^{-} ; \mathrm{NH}_{4}{ }^{+}: \mathrm{NO}_{3}{ }^{-} 1: 1\right.$; $\mathrm{NH}_{4}{ }^{+}: \mathrm{NO}_{3}{ }^{-} 1: 2$; and $\mathrm{NH}_{4}{ }^{+}: \mathrm{NO}_{3}{ }^{-} 2: 1$ ) and the subplot was cultivars (Crok Kuning, Tiron, and Bima Brebes). Each subplot covered an area of $2.5 \mathrm{~m}^{2}(2.5 \mathrm{~m} \mathrm{x} 1 \mathrm{~m})$ with three blocks as replications. Shallot bulbs were planted in sixth-row, spacing $20 \mathrm{~cm}$ between rows and $15 \mathrm{~cm}$ within rows. The dose was applied according to the recommendation of BPTP (urea $200 \mathrm{~kg} \mathrm{ha}^{-1}$, ZA $250 \mathrm{~kg} \mathrm{ha}^{-1}$, SP-36 $150 \mathrm{~kg} \mathrm{ha}^{-1}$, and $\mathrm{KCl} 150 \mathrm{~kg} \mathrm{ha}^{-1}$ ) $144.5 \mathrm{~kg} \mathrm{~N} \mathrm{ha}^{-1}$. Ammonium:nitrate ratio influenced shallot growth in sandy soil through number of leaves at maximum vegetative phase and its leaf area. The $\mathrm{NH}_{4}{ }^{+}: \mathrm{NO}_{3}{ }^{-} 1: 2$ ratio gave the best result in dry weight of leaves following bulb dry weight than other ratio. Nevertheless, ammonium:nitrate ratio had no significant influence on bulb dry weight (ton ha-1).
\end{abstract}

Keywords: Nitrogen Source, Sandy Soil, Shallots

\section{INTRODUCTION}

Shallots are an an important commercial commodity and the third cause of inflation in Indonesia. Nitrogen is a key for increasing the yield and quality of vegetables, such as shallots (Nori, 2012). Growth and development of plants are influenced by nitrogen form. Common plants prefer nitrate for growth, but the enormity preference varies within plant species and other environmental factors (Barker and Mills, 1980). Several scientists have studied the effects of different nitrogen levels on the growth and yield of shallot (Firmansyah and Sumarni, 2013; Sumarni et al., 2012; Sugiyarto et al., 2013; Woldetsadik, 2003; Koheri et al., 2015), but the effect of ammonium:nitrate ratio on growth and yield of shallot has never been reported.

In soils, ammonium concentrations are lower than nitrate, but roots can uptake ammonium at a very high rate. Ammonium uptake is a major importance for $\mathrm{N}$ nutrition when nitrification is inhibited (Wiren, 2001). Despite most plants' preferences for nitrate uptake, most species grow best if they have access to both nitrate and ammonium nitrogen (Errebhi and Wilcox, 1990). Gamiely et al. (1991) reported that onion bulb's dry weight was higher on $\mathrm{NH}_{4}{ }^{+}: \mathrm{NO}_{3}{ }^{-}$ $0: 1$ and $1: 3$ ratio in solution culture during winter and early spring under greenhouse conditions.

The effects of the form of nitrogen $\left(\mathrm{NH}_{4}{ }^{+}\right.$or $\left.\mathrm{NO}_{3}{ }^{-}\right)$ are found on several species in uptake, assimilation, photosynthesis growth and yield, but to our knowledge not in shallot. The purpose of this work was to study the effects of ammonium:nitrate ratio in sandy soil on the growth and yield of shallot (Allium cepa $\mathrm{L}$. Aggregatum group). 


\section{MATERIALS AND METHODS}

The experiment had been conducted in August-October 2015 in the sandy land on Samas Beach, Bantul, Yogyakarta, Indonesia. The research was arranged in a Split-Plot design. The main plot was the source of nitrogen $\left(\mathrm{NH}_{4}{ }^{+} ; \mathrm{NO}_{3}^{-} ; \mathrm{NH}_{4}^{+}: \mathrm{NO}_{3}^{-} 1: 1 ; \mathrm{NH}_{4}{ }^{+}: \mathrm{NO}_{3}^{-} 1: 2\right.$; and $\left.\mathrm{NH}_{4}{ }^{+}: \mathrm{NO}_{3}{ }^{-}{ }^{-2}: 1\right)$ and the subplot was cultivars (Crok Kuning, Tiron, and Bima Brebes). Each subplot covered an area of $2.5 \mathrm{~m}^{2}(2.5 \mathrm{~m} \mathrm{x} 1 \mathrm{~m})$ with three blocks as replicates. Shallots bulbs were planted in the sixth-row, spacing $20 \mathrm{~cm}$ between rows and 15 $\mathrm{cm}$ within rows. The dose was applied according to the recommendation of BPTP (urea $200 \mathrm{~kg} \mathrm{ha}^{-1}$, ZA $250 \mathrm{~kg} \mathrm{ha}^{-1}$, SP-36 $150 \mathrm{~kg} \mathrm{ha}^{-1}$, and KCl $150 \mathrm{~kg} \mathrm{ha}^{-1}$ ) $144.5 \mathrm{~kg} \mathrm{~N} \cdot \mathrm{ha}^{-1}$. The treatment source of N was applied twice in 12 and 20 dap, and organic matter of 30 ton ha-1 was applied before planting. The environmental temperature was monitored in $1,2,3,4,5,6,7$, and 8 week after planting (wap), and growth response of plants following morphological parameter was measured: number of leaves, leaf area, dry weight (leaf and root), and root length in 5 and 8 week after planting (wap). Whereas the yield parameters measured were bulb weight (fresh and dry) and productivity in 8 week after planting (wap). Statistical analysis used analysis of variance using Excel software ( $95 \%$ confidence levels) and mean comparison using Duncan multiple range test.

\section{RESULT AND DISCUSSION}

The observed temperature demonstrated a less requirement for shallot. The highest temperature was $43.2^{\circ} \mathrm{C}$ in the fourth week (Fig. 1). Shallot crop growing required $25-32{ }^{\circ} \mathrm{C}$ and $50-70 \%$ of temperature and humidity (Sumarni and Hidayat, 2005). Physiological processes were affected by temperature, such as stomata opening, photosynthesis, respiration, nutrient uptake, enzymes activities, taste, and flowering (Giyanto, 2014). High temperature could disturb the process, thus affected plant development and productivity (Hatfield and Prueger, 2015). The productivity of crop species fekk markedly at high temperature. Lafta and Lorenzen (1995) reported that high temperature reduced the growth of tubers more than the shoots on Solanum tuberosum L. Less requirement of shallot in this research allegedly decreased the growth and yield of shallot.

\section{Growth}

Numbers of leaves in maximum vegetative phase were influenced by cultivar in each ammonium:nitrate ratio (Table 1). The numbers of leaves in two cultivars, Crok Kuning and Tiron, were lower than Bima Brebes in ammonium:nitrate of 1:0, 1:1, and 1:2 ratio. Cultivar showed no difference with the application of ammonium:nitrate of 0:1 and 2:1 ratio. These data suggested that under the condition of this study, ammonium was more preferred than nitrate for number of leaves of shallot. Ammonium:nitrate availability increased more than the ammonium supply. However, ammonium presence could not exceed more than $50 \%$.

The leaf area of plants was influenced independently by cultivars and ammonium:nitrate ratio. The highest mature leaf area was achieved with the application of ammonium:nitrate of 1:2 ratio in 8 wap (Fig. 2). Aryani (2016) mentioned that shallot reached its vegetative maximum phase in 35 wap. These results showed that optimum leaves growth at $8 \mathrm{wap}$, and it

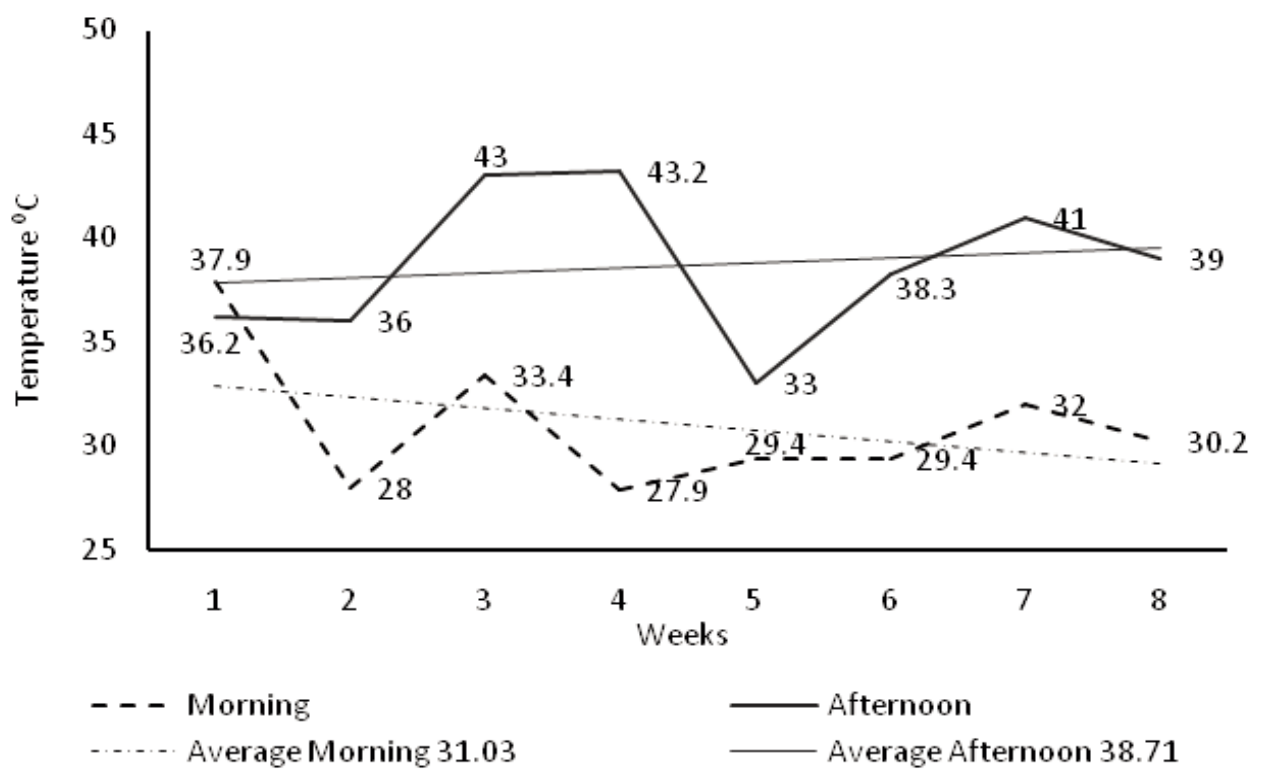

Figure 1. Air temperature $\left({ }^{\circ} \mathrm{C}\right)$ surrounding shallots plant in 8 weeks 
Table 1. Number of leave in 5 WAP observation

\begin{tabular}{lcccccc}
\hline \multirow{2}{*}{ Cultivar } & \multicolumn{5}{c}{$\mathrm{NH}_{4}^{+}: \mathrm{NO}_{3}{ }^{-}$ratio } & \multirow{2}{*}{ Average } \\
\cline { 2 - 6 } & $1: 0$ & $0: 1$ & $1: 1$ & $1: 2$ & $2: 1$ & 13.28 \\
\hline Crok Kuning & $13.38 \mathrm{def}$ & $9.54 \mathrm{f}$ & $12.33 \mathrm{ef}$ & $13.46 \mathrm{def}$ & $17.67 \mathrm{cdef}$ & 15.78 \\
Tiron & $10.67 \mathrm{ef}$ & $17.92 \mathrm{cdef}$ & $15.04 \mathrm{def}$ & $19.58 \mathrm{cde}$ & $15.67 \mathrm{def}$ & 25.48 \\
Bima Brebes & $25.71 \mathrm{abc}$ & $15.79 \mathrm{def}$ & $31.33 \mathrm{ab}$ & $32.00 \mathrm{a}$ & $22.54 \mathrm{bcd}$ & $(+)$ \\
Average & 16.58 & 14.42 & 19.57 & 21.68 & 18.63 & \\
\hline \multicolumn{7}{c}{$\mathrm{CV}=27.36 \%$} \\
\hline
\end{tabular}

Remarks: The numbers with same letters in the same column and/or rows showed no significant difference by Duncan's 5\%; $(+)$. There was interaction found between the factors tested.

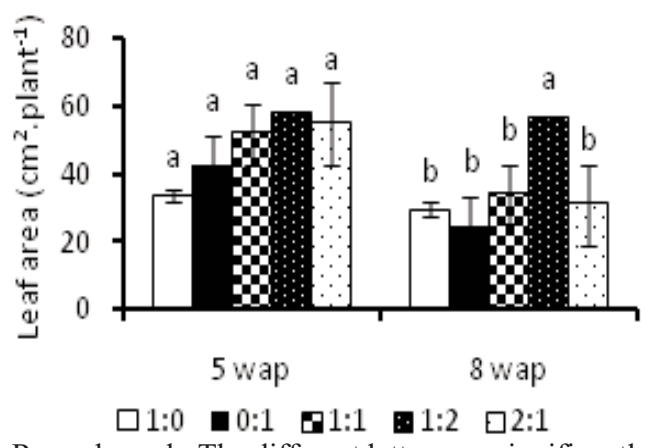

Remarks: $a, b$;The different letters are significantly different at $\mathrm{P} \leq 0.05$

Figure 2. The leaf area of shallot in each ammonium : nitrate ratio treatment

would extend the optimum bulb formation phase. Ammonium:nitrate ratio increased mature leaf area about $47 \%$, compared with other treatments. The highest leaf area in maximum vegetative phase was obtained by Bima Brebes cultivar (Fig. 3). The same result was shown by Bima Brebes cultivar in mature leaf area ( 8 wap). Bima Brebes cultivar leaf area was higher than others, both in maximum vegetative phase and maturity, $65 \%$ and $45 \%$ respectively. Poorer leaf areas of Crok Kuning and Tiron were caused by the low number of leaf produced.

Ammonium:nitrate ratio and cultivars were independently affect the dry weight of leaves, roots, bulb, and total (Fig. 4). The distribution assimilation (dry weight) had the same pattern on both treatments, i.e. highest on the bulb at 3 wap; and maximum vegetative phase at 5 wap was the highest on leaf, then it was concentrated on the bulb at 8 wap. Ammonium:nitrate ratio indicated only significant difference in dry weight of leaves and roots in 8 wap, but not the bulb. The 1:2 and 1:1 ratio were allegedly prolong the vegetative phase, so the growth of leaf reached its optimum at 8 wap. Thus, it impacted the elongated optimum bulb ripening phase. Cultivar treatments were significantly different in leaves and roots at 5 wap (Fig. 4E). Bima Brebes cultivar showed highest dry weight on leaves and roots, and resulted in the high dry weight of bulb at 8 wap (Fig. 4F).

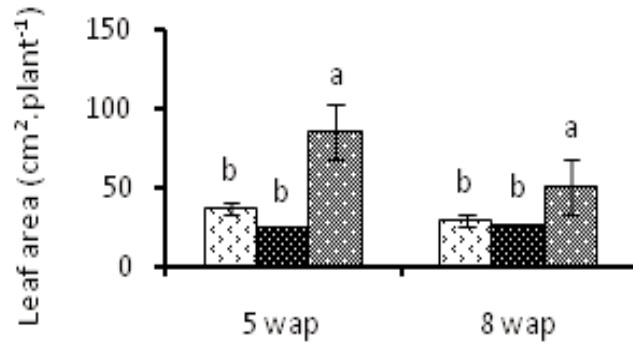

ⒸrokKuning Tiron Bima Brebes

Remarks: $\mathrm{a}, \mathrm{b}$; The different letters are significantly different at $\mathrm{P} \leq 0.05$

Figure 3. The leaf area of shallotin cultivar treatment

Harvest Index (HI) described the ability of plants to distribute assimilation to bulbs. Cultivars provided independent influence on $\mathrm{HI}$ at 5 wap (Table 2). Bima Brebes cultivar had the lowest $\mathrm{HI}$ in comparison with other cultivars because assimilation was used to optimise leaves growth (Fig. 4E). The highest HI showed by Crok Kuning and Tiron, indicated that both cultivars distributed the assimilation to the bulb. HI was not significantly different in the treatments, both ammonium:nitrate ratio and cultivars, at 8 wap. The optimisation of vegetative phase of Bima Brebes cultivar did not influence HI, but it resulted in the highest dry weight of bulb in 8 wap. The highest dry weight of bulb in Bima Brebes cultivar might increase production.

Ammonium:nitrate ratio was not significant to root length in both 5 wap and 8 wap (Fig. 5). Differences in root length was shown by cultivars. The highest result was shown by Bima Brebes (Fig. 6). Sas et al., (2003) reported that strawberry (Fragaria ananassa) influenced nitrogen form in root length with lower nitrate and ammonium sole treatment. These data suggested that this study on ammonium:nitrate ratio affected the growth of the canopy in comparison with underground of plants. Despite significant difference occurred in root dry weight at 8 wap, it did not influence the increase in yields.

The result showed that ammonium:nitrate ratio 

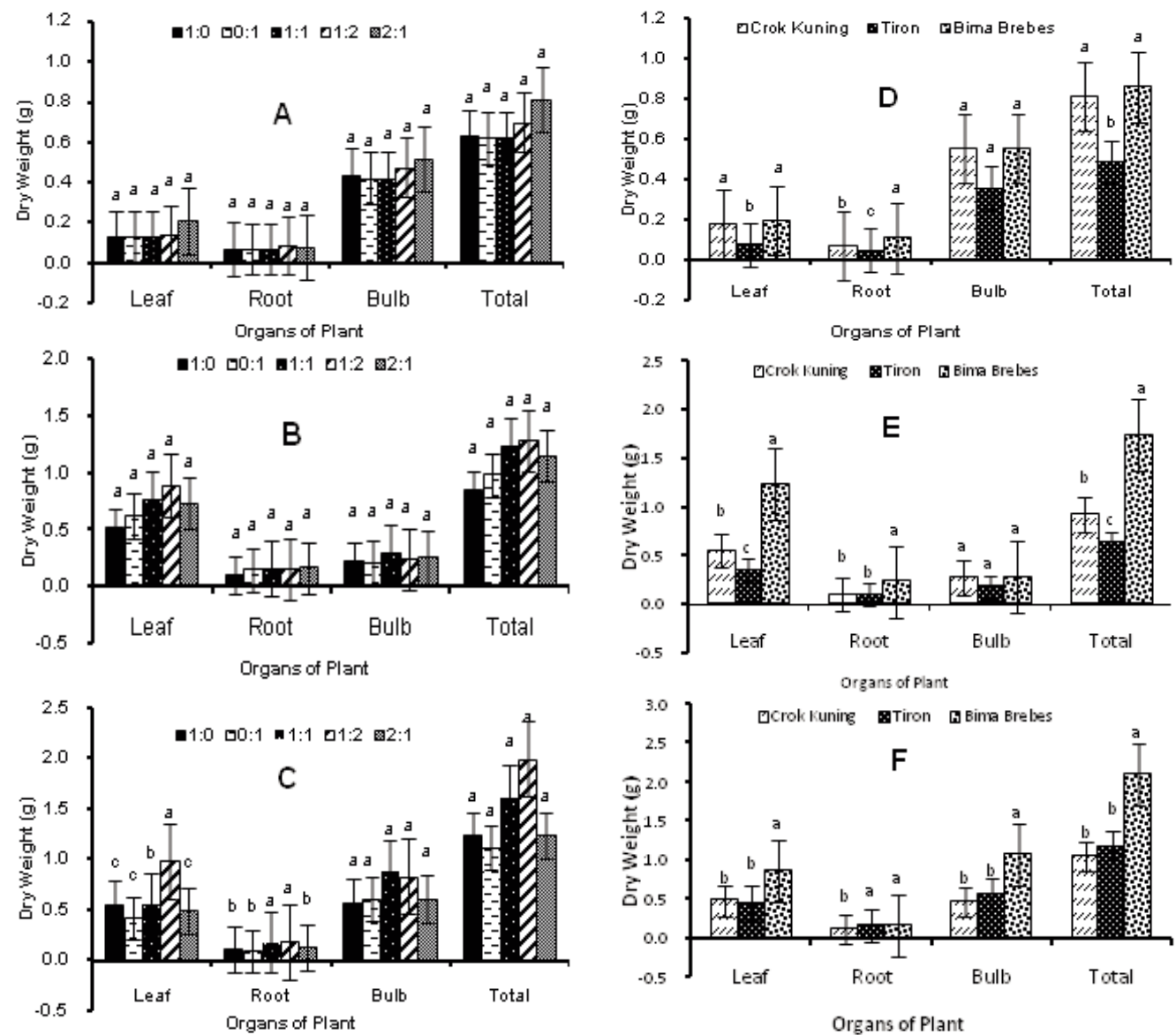

Remarks: $\mathrm{a}, \mathrm{b}$; The different letters are significantly different at $\mathrm{P} \leq 0.05$

Figure 4. Distribution of dry weight of shallot plant based on nitrogen ratio at (A): 3 wap, (B): 5 wap, (C): 8 wap, and cultivars at (D): 3 wap, (E): 5 wap, and (F): 8 wap

Table 2. Harvest Index of shallot in 5 and 8 WAP

\begin{tabular}{|c|c|c|}
\hline \multirow{2}{*}{ Treatment } & \multicolumn{2}{|c|}{ Harvest Index (HI) } \\
\hline & 5 wap & 8 wap \\
\hline \multicolumn{3}{|l|}{$\mathrm{NH}_{4}{ }^{+}: \mathrm{NO}_{3}{ }^{-}$ratio } \\
\hline $1: 0$ & $0.32 \mathrm{a}$ & $0.42 \mathrm{a}$ \\
\hline $0: 1$ & $0.27 \mathrm{a}$ & $0.48 \mathrm{a}$ \\
\hline $1: 1$ & $0.26 \mathrm{a}$ & $0.49 \mathrm{a}$ \\
\hline $1: 2$ & $0.20 \mathrm{a}$ & $0.39 \mathrm{a}$ \\
\hline $2: 1$ & $0.23 \mathrm{a}$ & $0.46 \mathrm{a}$ \\
\hline Average & 0.26 & 0.45 \\
\hline \multicolumn{3}{|l|}{ Cultivar } \\
\hline Crok & $0.31 \mathrm{a}$ & $0.45 \mathrm{a}$ \\
\hline Tiron & $0.29 \mathrm{a}$ & $0.40 \mathrm{a}$ \\
\hline Bima & $0.17 \mathrm{~b}$ & $0.49 \mathrm{a}$ \\
\hline Average & 0.26 & 0.45 \\
\hline CV $(\%)$ & 9.08 & 7.49 \\
\hline Interaction & - & - \\
\hline $\begin{array}{r}\text { Remarks: The nun } \\
\text { significa } \\
\text { found } b \\
\sqrt{ }(x+0.5)\end{array}$ & $\begin{array}{l}\text { me lette } \\
\text { by Dunc } \\
\text { factor } t\end{array}$ & $\begin{array}{l}\text { umn sho } \\
\text { o interac } \\
\text { ansform }\end{array}$ \\
\hline
\end{tabular}




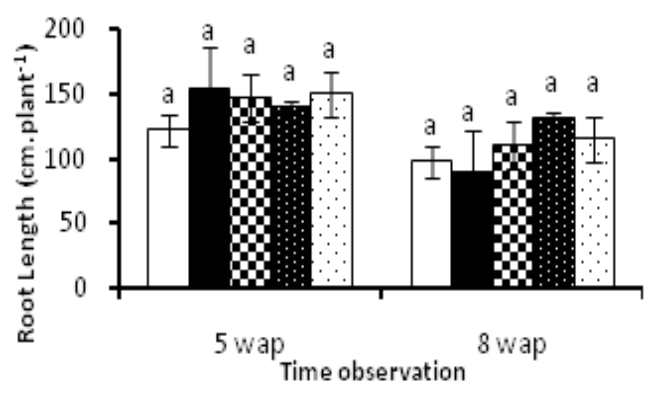

$\square 1: 0$ 口 $0: 1$ 田:1: $1: 2$ 口2:1

Remarks: $a, b$; The different letters are significantly different at $\mathrm{P} \leq 0.05$

Figure 5. Root length of shallot plantsin each ammonium:nitrate ratio treatment

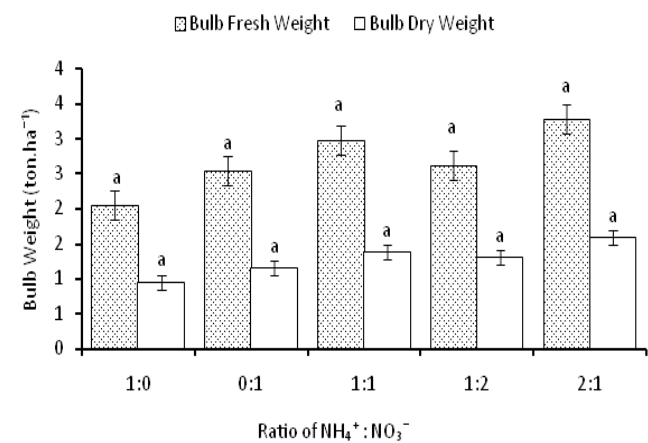

Remarks: $a, b$; The different letters are significantly different at $\mathrm{P} \leq 0.05$

Figure 7. The yield of shallot based on nitrogen ratio at 8 wap

and cultivars had an independent effect on yield (Fig. 7 and Fig. 8). The prolonged vegetative phase caused by the application of ammonium:nitrate ratio had an impact, but not to optimal charging of bulb at harvest time. Fig. 7 demonstrated that sole ammonium treatment caused lowest productivity, both on fresh and dry bulb. Allegedly, shallot plants preferred nitrate than ammonium, but the availability of both ammonium and nitrate could increase yield. The highest productivity was shown by Bima Brebes. The growth variable of Bima Brebes was higher than Crok Kuning and Tiron cultivars, and the optimal growth by cultivar was proven to increase the yield than others.

The productivity of Bima Brebes cultivar was the highest, compared with other cultivars because it had better growth. However, Tiron had lower fresh weight compared with Crok, but no difference was found in dry weight. The description of cultivars by District Agriculture Office of Bantul demonstrated that weight loss in Crok Kuning was lower than Tiron, at $10-20 \%$ and $30 \%$, respectively. These results proved that cultivar was affected by nitrogen ratio, such as prolonged vegetation and charging bulb phase; and the result of charging bulb was not optimal at harvest time.

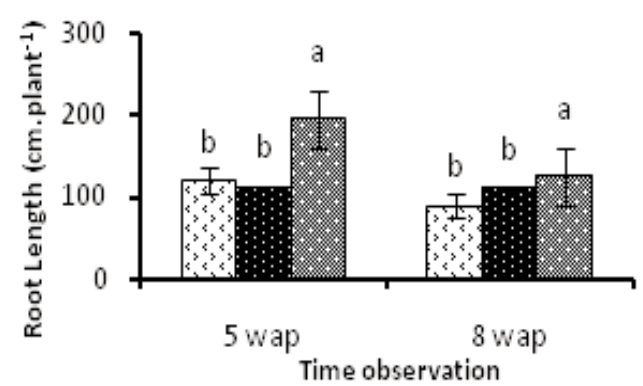

a CrokKuning $\mathbf{z}$ Tiron Bima Brebes

Remarks: $a, b$; The different letters are significantly different at $\mathrm{P} \leq 0.05$

Figure 6. Root length of shallot in each cultivars treatment.

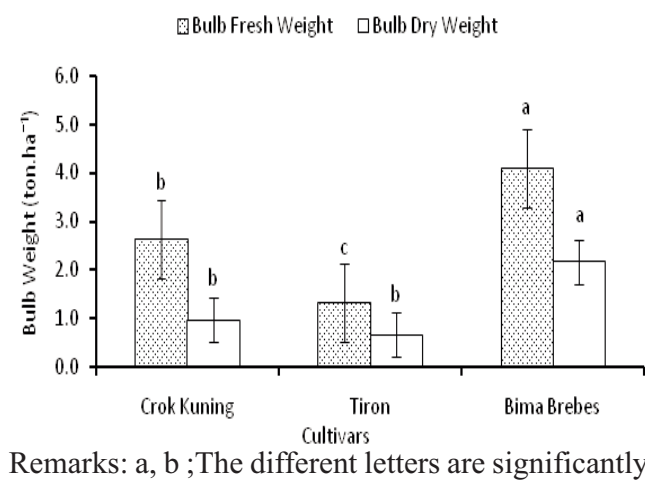
different at $\mathrm{P} \leq 0.05$

Figure 8. The yield of shallot based on cultivars at 8 wap

\section{CONCLUSION}

Ammonium:nitrate ratio influenced shallot growth in sandy soil through number of leaves in maximum vegetative phase and leaf area. The 1:2 ratio of $\mathrm{NH}_{4}^{+}: \mathrm{NO}_{3}^{-}$gave the best result for leaves dry weight following bulb dry weight, compared with other treatments. Nevertheless, ammonium:nitrate ratio had non-significant influence on bulb yield's dry weight (ton ha-1).

\section{ACKNOWLEDGEMENT}

We thank to Australian Centre for International Agricultural Research for the financial support they provided.

\section{REFERENCES}

Aryani, N. 2016. Pengaruh Pemberian Vermikompos dan Pupuk Pelengkap terhadap Produksi Tanaman Bawang Merah Tuk - Tuk (Allium ascalonicum L.) dan Beberapa Sifat Kimia Tanah Ultisol. Skripsi. Fakultas Pertanian Universitas Lampung.

Barker, A.V. and H.A. Mills. 1980. Ammonium and Nitrate Nutrition of Horticultural Crops. Hort.Rev., 2: 395-423

Errebhi, M., and G. E. Wilcox. 1990. Plant Species Response to Ammonium-Nitrate Concentration 
Ratios. Journal of Plant Nutrition, 13(8): 1017-1029.

Firmansyah, I. and N. Sumarni. 2013. Effect of $N$ Fertilizer Dosages and Varieties On Soil $\mathrm{pH}$, Soil Total-N, N Uptake, and Yield of Shallots (Allium ascalonicum L.) Varieties On Entisols - Brebes Central Java. Bandung Barat: Balai Penelitian Tanaman Sayuran.

Gamiely, S., W. M. Randle, H. A. Mills, and D.A. Smittle. 1991. Onion Plant Growth, Bulb Quality, and Water Uptake Following Ammonium and Nitrate Nutrition. HORTSCIENCE, 26(8): 1061-1063.

Giyanto, A. 2014. Pengaruh Faktor Suhu terhadap Pertumbuhan Tanaman. Indralaya: Universitas Sriwijaya.

Hatfield, J. L. and J. H. Prueger. 2015. Temperature Extreme: Effect on Plant Growth and Development. Water and Climate Extremes, 10(A): 4-10.

Koheri, A., Mariati, dan T. Simanungkalit. 2015. Tanggap Pertumbuhan dan Produksi Bawang Merah (Allium ascalonicum, L.) terhadap Waktu Aplikasi dan Konsentrasi Pupuk $\mathrm{KNO}_{3}$. Jurnal Online Agroekoteknologi, 3 (1): 206-213.

Lafta, A. M. and J. H. Lorenzen. 1995. Effect of High Temperature on Plant Growth and Carbohydrate Metabolism in Potato. Plant Physiol, 109: 637-643.

Nori, M., J. Aali, and R. ShafiriAsl. 2012. Effect of Different Sources and Levels of Nitrogen Fertilizer on Yield and Nitrate Accumulation in Garlic (Allium sativum L.). Intl J Agri Crop Sci., 4
(24): $1878-1880$.

Sas, L., H. Marscher, V. Romheld, and S. Mercik. 2003. Effect of Nitrogen Forms on Growth and Chemical Changes in Rhizosphere of Strawberry Plants. ACTA PHYSIOLOGIAE PLANTARUM, 25 (3): 241-247.

Sumarni, N. dan A. Hidayat. 2005. Budidaya Bawang Merah. Bandung: Balai Penelitian Tanaman Sayuran.

Sumarni, N., R. Rosliani, dan R. S. Basuki. 2012. Respon Pertumbuhan, Hasil Umbi, dan Serapan Hara NPK Tanaman Bawang Merah Terhadap Berbagai Dosis Pemupukan NPK pada Tanah Alluvial. J. Hort., 22(4): 366-375.

Sugiyarto, M., dan J. Ginting. 2013. Respon Pertumbuhan dan Produksi Beberapa Kultivar Bawang Merah (Allium ascalonisum L.) terhadap Berbagai Sumber Nitrogen Organik. Jurnal Online Agroekoteknologi, 2 (1): 402-410.

Wiren, N. V., A. Gojon, S. Chaillou, and D. Raper Jr. 2001. Mechanism and Regulation of Ammonium Uptake in Higher Plants. In: P. J. Lea et al. (eds.), Plant Nitrogen. Berlin Heidelberg: Springer-Verlag, pp. 61-77.

Woldetsadik, K., U. Gertsson, and J. Ascard. 2003. Response of Shallot to Mulching and Nitrogen Fertilization. HortScience, 38(2): 217-221. 